\title{
Oogenesis of Lithodes santolla: histological and histochemical characterization
}

\author{
Guadalupe F. Arcos-Ortega ${ }^{1,2}$, Santos Rene Serrano-Silvas ${ }^{1}$, Carmen Rodríguez-Jaramillo ${ }^{2}$ \\ Eliana Paola Acuña-Gómez ${ }^{1}$, Diana C. Schofield-Astorga ${ }^{1}$ \& Carlos D. Olave-Solar ${ }^{1}$ \\ ${ }^{1}$ Línea de Ecosistemas Acuáticos, Centro de Estudios del Cuaternario de Fuego Patagonia y Antártica \\ Fundación CEQUA, Punta Arenas, Magallanes y Antártica Chilena, Chile \\ ${ }^{2}$ Centro de Investigaciones Biológicas del Noroeste (CIBNOR), La Paz, Baja California Sur, México \\ Corresponding author: Guadalupe F. Arcos Ortega (fabiola.arcos@cequa.cl)
}

\begin{abstract}
Although Lithodes santolla is a resource with high commercial importance that has aroused interest in controlled reproduction in captivity, currently, little knowledge is available about basic reproductive aspects of this species. This research study describes detailed oogenesis stages at the histological level in adult females of the southern king crab of the Magellan and Chilean Antarctic Region. Oogenesis was quantitatively analyzed from the proliferation of 10-24 $\mu \mathrm{m}$ oogonia and during oocyte growth. Five stages of ovary development were identified: multiplication (0), previtellogenesis (I), vitellogenesis (II), maturity (III) and spawning (IV). Furthermore, 11 oocyte substages were distinguished: oogonia, chromatin nucleolus, early perinucleolus, late perinucleolus, oil globule, early vitellin globule, late vitellin globule, postvitelogenic, germinal vesicle migration and germinal vesicle breakdown. Primary vitellogenesis occurred in oocytes 180$185 \mu \mathrm{m}$, containing acidophilic globules and surrounded by a layer of thick follicle cells (20-40 $\mu \mathrm{m})$. Secondary vitellogenesis was evident in oocytes at 315-321 $\mu \mathrm{m}$ with numerous acidophilic granules in the cytoplasm and surrounded by thin follicle cells; then, cortical crypts appeared, indicating the prematuration stage and preparation for ovulation. This study allows establishing gonadic changes that occur during a reproductive cycle of female L. santolla and help to strengthen aquaculture initiatives and management in the Magellan and Chilean Antarctic Region.
\end{abstract}

Keywords: Lithodes santolla; oogenesis; gonad maturity; quantitative histology; Magellan and Chilean Antarctic Region

\section{INTRODUCTION}

The king crab, Lithodes santolla, also known as the southern king crab, Magellanic centolla, Patagonian centolla, Chilean centolla or common king crab, is like the North Pacific king crab, Paralithodes camtschaticus. The southern king crab is one of the main fisheries of the Magellan and Chilean Antarctic Region and an important source of foreign currency, exchange and jobs in the region (SUBPESCA, 2014; Webb, 2014).

The crab fishery uses the strategy known as "SSS" (size, sex, season), with size regulation, the prohibition of landing females and a closed season to protect the reproductive process. In addition, fishing effort is made through the regulation of fishing gear and control of the number of vessels, prohibiting the entry of new units
(SUBPESCA, 2014). A ban from December 1 has restricted the fishing season until June 30 of the following year. The historic technical sustenance of this prohibition, which was developed during the 19801990 decade, is based on the knowledge of the reproductive process. The regulation is still in force but requires the revision and validation of the changes that the fishing activity and the environment have suffered (SUBPESCA, 2014). Considerable information on gonadic development is still necessary to understand the reproductive process of the species.

Gonadic development associated with the reproductive cycle of aquatic organisms is often established using macroscopic scales of sexual maturity, gonadic indices and condition factor, which frequently do not agree with the dynamics and gonadal functioning cycle 
(Palacios et al., 1999; Peixoto et al., 2003; FeitosaSilva \& Da Cruz-Landim, 2006; Castiglioni et al., 2007). In some crustacean decapods, such as prawn and shrimp, ovarian development can be visualized by shining a light through the transparent carapace of the animal (Ceballos-Vázquez et al., 2003; Bembe, 2009; Alfaro-Montoya, 2013), but in many crab species, including $L$. santolla, the carapace is opaque, and this technique cannot be used.

Histological analysis of the reproductive system of aquatic organisms has led to more complete knowledge of the gonad functions and provides high precision in characterising the oogenesis phases and the reproductive cycle of any species (Johnson, 1980; Yano, 1988; Tan-Fermin \& Pudadera, 1989; Minagawa et al., 1993; Rodríguez-Jaramillo et al., 2008; Kodama et al., 2009; Santos et al., 2009; Ravi et al., 2012; Smija \& Sudha-Devi, 2015).

Cytological and histological studies of L. santolla have shown the development of sex cells in males and females (Vinuesa, 1984; Vinuesa \& Labal de Vinuesa, 1998; Lovrich \& Vinuesa, 2016), and established that oogenesis in females is a cycle that lasts 20 to 23 months; two parallel gametogenic cycles in the ovaries occur. As a result, oocytes will also mature annually, before oviposition. In $L$. santolla females, gonad maturity is evident externally when they carry eggs because they extrude the oocytes at the moment of the copulatory embrace and fertilization; size at sexual maturity has been established with this information (SUBPESCA, 2014; Lovrich \& Vinuesa, 2016). Size at sexual maturity is an important parameter in a population to define the fraction of sexually active population and make decisions about population status (sex ratio, operational and the proportion of ovigerous females), which is also advantageous for managing fisheries because any failure in reproduction can be detected after the copulation period. However, the term "sexual maturity" in L. santolla and other lithodids is still unclear. In the literature, it has been interpreted ambiguously, but it was clearly defined by SainteMarie et al. (1995) and Sampedro et al. (1999). This terminology tends to be standardized in the literature of the last decade where different terms have been used to describe maturity stages (Sampedro et al., 1999).

Therefore, the objective of this study was to gain knowledge of basic reproductive aspects of the southern king crab, especially the characterization of the oogenesis phases from the histological and histochemical points of view.

\section{MATERIALS AND METHODS}

\section{Sampling and tissue processing}

During reproductive and non-reproductive seasons, a total of 312 L. santolla adult females were caught with a king crab trap on board traditional fishing vessels, under fishing permit SUBPESCA, Magallanes No3-101 along the coastal fiords and channels of the Magellan and Chilean Antarctic Region during the sampling years of 2012 (89 ind), 2013 (51 ind), 2014 (75 ind) and 2015 (97 ind). The crab specimens ranged to about $133.8 \pm 18.1 \mathrm{~mm}$ of carapace length (CL) and about $1.99 \pm 0.396 \mathrm{~kg}$ of total body weight (TW).

Reproductive tissues were dissected from freshly sacrificed females, and the gonadosomatic index (GSI) was calculated as a percentage of the wet weight of reproductive tissues (gonad weight, $\mathrm{GW}$ ) relative to the wet weight of the entire female (TW) (López-Greco \& Rodríguez, 1999). Weights were measured to the nearest $0.01 \mathrm{~g}$. Ovary lobes (anterior, middle and posterior regions) were carefully dissected from the abdominal cavity and fixed in Davison's solution (Humanson, 1979) to identify oogenesis stages by histological analysis.

\section{Histological analysis}

The fixed ovary lobes were dehydrated in ascending ethanol series, $70,80,95 \%$ and $100 \%$ ) cleared in xylene and embedded in paraffin (Paraplast X-Tra, Mc Cormick Scientific, San Diego, CA, USA). Slides were prepared in $4 \mu \mathrm{m}$ thick sections using a rotary microtome (Leica RM 2155, Leica Microsystems, Germany) and mounted on glass slides. Sections were stained for $5 \mathrm{~min}$ (Leica ST5020 Multistainer; Leica Microsystems) with Harris's hema-toxylin (SJV Grupo Bioquímico Médico, México), and counterstained with eosin-phloxine for $12 \mathrm{~min}$, to visualize the gonadal development stage of each sample. Slides were observed under a light microscope (Olympus BX50, Olympus Optical, Japan) equipped with a digital camera. The photomicrographs were digitalized with Image-Pro Premier 9.0 software. The histological characterization of crustacean decapods was revised for crabs (Varadarajan \& Subramoniam, 1980; Santos et al., 2009; Smija \& Sudha-Devi, 2015), shrimp (Yano, 1988; Tan-Fermin \& Pudadera, 1989; Kodama et al., 2009; El-Sheriff et al., 2012), and lobsters (Minagawa \& Sano, 1997; Feitosa-Silva \& Da Cruz-Landim, 2006).

\section{Oocyte area and diameter measurements}

Each slide was digitalized at high resolution (600 dpi; 40x) and processed in triplicate with Image-Pro Premier 2D version 9.2 for calculating total area $(A)$ and theoretical mean diameter $(T D)$ of each oocyte type to characterize detailed stages of oogenesis. Only were oocytes with a clearly defined nucleus considered for calculating $A$. The $T D$ was calculated from $A$ of each oocyte, using the formula by Saout et al. (1999): $T D=$ $\sqrt{4 \mathrm{~A}} / \pi$. 


\section{Histochemical analysis}

Slides of ovary tissue were also stained with Sudan Black B to identify lipids (Bayliss, 1984). Finished slides were observed (40x) with a research microscope equipped with a camera, digitalized at high resolution (600 dpi; 40x), and processed in triplicate through an image signal technique standardized by RodríguezJaramillo et al. (2008), using Image-Pro Premier 9.0 software. The pixel proportion of the total represented a proportion of the lipids present in each oocyte. This technique is based on the conversion of the image color to an intensity level image to enhance a specific dye (Otsu, 1979). Lipid indices were calculated by the formula of Rodríguez-Jaramillo et al. (2008): Lipid index $=(\mathrm{SAC} / \mathrm{AT}) \times 100$ where SAC is the total coverage area of five images and AT is the number of total images of the area, expressed in $\mu \mathrm{m}^{2}$. The same formula was used for calculating the lipid index of each identified oocyte substage. In this case, SAC is the total coverage area of oocytes and AT is the total oocyte area, both expressed in $\mu \mathrm{m}^{2}$.

\section{Statistical analysis}

Histological quantitative data (TD) were transformed to logarithm base 10 to determine statistical differences between the oogenesis stages and among years of sampling, and percentage-expressed values (GSI and Lipid index) were arcsine transformed to fit a normal distribution (Zar, 1999). Two One-way analyses of variance (ANOVA) were performed using the transformed data, considering "stages of oogenesis" and "years of sampling" as factors separately. All statistical analyses were performed with the General Linear Model (GLM) of statistical software StatSoft 10. The level of statistical significance was set at $P<0.05$. When statistical differences were found, the means were compared with the Tukey post-hoc test. Backtransformed means were calculated, and standard errors were those obtained from untransformed variables.

\section{RESULTS}

Morphologic variables and those related to gonad development (Gonadosomatic index (GSI), theoretical mean diameter (TD) and lipid index) of females collected between 2012 and 2015 are shown in Table 1. Significant differences $(P<0.05)$ were found between carapace length (CL) of females collected in the different years; the CL of females collected in 2014 was slightly lower. The total body weight of females collected in 2013 and 2015 was significantly higher $(P$ $<0.05)$ than that of females collected in 2012 and 2014. Regarding the GSI, the ANOVA analysis showed significant differences $(P<0.05)$ among the females collected during the different sampling years. Females collected in 2015 had the highest values. About the TD, females collected in 2015 also had the highest values $(P$ $<0.05)$. Lipid index was significantly lower $(P<0.05)$ in females collected in 2012 whereas it was similar in females collected in 2013, 2014 and 2015.

\section{Histological characterization of oogenesis}

The reproductive system of female Lithodes santolla follows the anatomical pattern observed in other Anomura crabs, such as $P$. camtschaticus (Webb, 2014). The female reproductive system consists of paired ovaries (dorsum-lateral to the digestive system, and connected in the middle, as an "H" shape) and oviducts, which are connected to gonopores located on the ventral surface of the exopodites of the second pereiopods.

The cells that constitute $L$. santolla ovaries are of three main types: oogonia, oocytes in different stages of development and follicle cells. The oocytes in the ovary undergo a series of morphological and biochemical changes, such as degree of yolk accumulation during development.

The differences found between ovary cells by qualitative and quantitative histological analyses lead us to classify Lithodes santolla oogenesis into five sequential stages (Table 2): 0 multiplication, I previtellogenesis, II vitellogenesis, III maturity and IV spawning. Furthermore, according to their cellular characteristics, 11 oocytes substages were distinguished: 1) oogonia (Og), 2) chromatin nucleolus (Cn), 3 ) early perinucleolus (Pn1), 4) late perinucleolus $(\mathrm{Pn} 2), 5)$ oil globule (Li), 6) yolk globule (yg), 7) early vitellin globule (Ev1), 8) late vitellin globule (Vo2), 9) postvitelogenic (Pvo), 10) germinal vesicle migration (Gvm), and 11) germinal vesicle breakdown (Gvb) (Fig. 1; Table 2).

Oogonia are cells characterized by one basophilic nucleolus; dispersed chromatin, extremely narrow and weakly basophilic cytoplasm (Fig. 1a). These cells are spherical, and their diameter ranged from 10-24 $\mu \mathrm{m}$. Oogonia were detected in the central germinal zone in multiplication, previtellogenic and vitellogenic (primary and secondary) stages and the mature stage of oogenesis.

The chromatin nucleolus, early chromatin perinucleolus and late chromatin perinucleolus oocytes were observed in the previtellogenic stage, (Figs. 1b-1d). The chromatin nucleolus measured 49-52 $\mu \mathrm{m}$ in diameter. The early chromatin perinucleolus oocytes measured 78 to $80 \mu \mathrm{m}$ in diameter and were found close to the oogonia with a weakly basophilic cytoplasm (Fig. 1c). Additionally, some materials were observed in the basophilic nucleus. A large, round and strongly basophilic nucleolus was centrally located in the nucleus with six or seven circular nucleoli situated peripherally. 
Table 1. Mean \pm standard error of morphometric variables (carapace length and total body weight), gonadosomatic index (GSI), theoretical mean diameter (TD) and lipid index of Lithodes santolla females collected along the coastal fiords and channels of the Magellan and Chilean Antarctic Region, during the sampling years. *Gonadosomatic index (GSI) was calculated as wet gonad weight $[(\mathrm{GW}) /$ wet weight of the entire female $(\mathrm{TW})] \times 100$. Superscript letters indicate significant differences after a one-way ANOVA $(P<0.05)$ and Tukey test.

\begin{tabular}{lcccr}
\hline \multirow{2}{*}{ Years of sampling } & 2012 & 2013 & 2014 & 2015 \\
& $\mathrm{n}=89$ & $\mathrm{n}=51$ & $\mathrm{n}=75$ & $\mathrm{n}=97$ \\
\hline Carapace length $(\mathrm{mm})$ & $132.5 \pm 14.20^{\mathrm{b}}$ & $146.1 \pm 17.02^{\mathrm{c}}$ & $116.4 \pm 14.01^{\mathrm{a}}$ & $145.2 \pm 20.01^{\mathrm{c}}$ \\
Total body weight $(\mathrm{kg})$ & $0.964 \pm 0.21^{\mathrm{a}}$ & $1.71 \pm 0.34^{\mathrm{b}}$ & $0.721 \pm 0.37^{\mathrm{a}}$ & $1.73 \pm 0.49^{\mathrm{b}}$ \\
Gonadosomatic index $(\%)^{*}$ & $2.68 \pm 0.65^{\mathrm{a}}$ & $5.12 \pm 0.40^{\mathrm{b}}$ & $4.46 \pm 0.60^{\mathrm{b}}$ & $6.05 \pm 0.89^{\mathrm{c}}$ \\
Theoretical mean diameter $(\mu \mathrm{m})$ & $213.0 \pm 139.50^{\mathrm{a}}$ & $318.22 \pm 0.51^{\mathrm{b}}$ & $318.22 \pm 5.95^{\mathrm{b}}$ & $475.05 \pm 72.31^{\mathrm{c}}$ \\
Lipid index $(\%)$ & $71.9 \pm 20.50^{\mathrm{a}}$ & $85.3 \pm 5.21^{\mathrm{b}}$ & $82.6 \pm 2.32^{\mathrm{b}}$ & $90.5 \pm 2.90^{\mathrm{b}}$ \\
\hline
\end{tabular}

The cytoplasm was strongly basophilic. Very few follicle cells were visible around the oocytes (Fig. 1d).

For late perinucleolus oocytes, the diameter was 124-130 $\mu \mathrm{m}$ in thickness. A large, round and strongly basophilic nucleolus was centrally located in the nucleus with five or six circular nucleoli peripherally situated. The cytoplasm was strongly basophilic (Figs. 1c-1d). Follicle cells were visible on the outer surface of the oocyte (Fig. 1d). The follicle layer consisted of a single layer with 30 to 40 basophilic cells $(4-10 \mu \mathrm{m}$ in thickness) through the largest diameter cross-section. Late perinucleolus oocytes had a well-defined nucleus with prominent nucleoli on the border (Fig. 1d).

In the primary vitellogenesis stage, oil globule oocytes measured 180-185 $\mu \mathrm{m}$ in diameter. The cytoplasm was weakly basophilic although numerous acidophilic globules (2-12 $\mu \mathrm{m}$ in diameter) were found in the cytoplasm (Fig. 1e). During this stage, the nucleus, situated at the center of the oocyte, shrank rapidly to a diameter of $15-30 \mu \mathrm{m}$. As a result, the nucleus was less visible at this stage. Follicle cells on the outer surface of the oocyte expanded rapidly to measure $20-40 \mu \mathrm{m}$ in thickness. A late follicle consisted of 25-40 cells through the largest diameter crosssection. The nucleus was indistinct in the follicle cells, and much of the expanded cell was strongly acidophilic. A strongly positive Sudan Black B staining indicated that these droplets were oil globules (Fig. 2c). In the early developing ovaries, oil globule and yolk globule oocytes appeared for the first time (Fig. 1g). Early vitellin globule oocytes were also observed (Fig. 1f) with $226-232 \mu \mathrm{m}$ in diameter. The cytoplasm was basophilic, and a large oil globule (20-30 $\mu \mathrm{m}$ in diameter) was observed in the peripheral cytoplasm. The nuclei expanded again to measure $30 \mu \mathrm{m}$ in diameter. The follicle cells were basophilic with indistinct nuclei. The follicle cells measured 10-12 $\mu \mathrm{m}$ in thickness.
In the secondary vitellogenesis stage, late vitellin globule oocytes measured $315-321 \mu \mathrm{m}$ in diameter. Nuclei measured $20-70 \mu \mathrm{m}$ in diameter and were observed centrally in the cytoplasm with several circular nucleoli peripherally situated (Fig. 1h). In the acidophilic cytoplasm, some strong vesicles (5-8 $\mu \mathrm{m}$ in diameter) were observed, and several acidophilic yolk granules $(5-10 \mu \mathrm{m}$ in diameter) were found within the vesicles. Follicle cells measured $8-10 \mu \mathrm{m}$ in thickness. At this stage, yolk granules were first concentrated centrally, and then gradually spread peripherically (Fig. 1h).

During the secondary vitellogenesis stage, the histological sections showed a prominence $(80 \%)$ of secondary vitellogenic stage oocytes (late vitellin globule oocytes), which occupied a considerable portion of the ovary; a few previtellogenic oocytes (chromatin nucleolus, early chromatin perinucleolus and late chromatin perinucleolus) were found (20\%) interspersed among the vitellogenic oocytes.

In the maturity stage, postvitellogenic oocytes measured 455-468 $\mu \mathrm{m}$ in diameter. Accumulation of yolk granules was still observed in the cytoplasm (Fig. 1i). The nuclei measured $100-130 \mu \mathrm{m}$ in diameter in the early phase of this stage and began migrating to the periphery. Large and round nucleoli were still observed, and follicular cells were flatter, and only one had a prominent and rounded nucleolus. In the late phase of this stage, yolk granules occurred in germinal vesicle migration oocytes, which were characterized by a large size and a high number of oocytes (Figs. 1j-11). Yolk granules were acidophilic and rich in triglycerides (Fig. 2f). In the late phase of this stage, the germinal vesicle breakdown of oocytes appeared, measuring $560-580 \mu \mathrm{m}$ in diameter (Fig. 1n). Oocytes contained an extensive accumulation of acidophilic yolk granules dispersed throughout the cytoplasm. This oocyte type was mainly observed in ripe ovaries. Histologically, the ovary was filled (95\%) with postvitellogenic and germi- 
Table 2. Histological description of the oogenesis stages of identified in adult Lithodes santolla females.

\begin{tabular}{|c|c|c|c|}
\hline Gonad extern morphology & $\begin{array}{c}\text { Stages of } \\
\text { oogenesis }\end{array}$ & Oocyte substages & Histological description \\
\hline Light yellow, translucent color & 0 Multiplication & 1) Oogonia & $\begin{array}{l}\text { Only are oogonias found in mitotic multiplication } \\
(\mathrm{Og} ; \mathrm{Om}) \text {. }\end{array}$ \\
\hline Cream or milky white color & I Previtellogenesis & $\begin{array}{l}\text { 2) Chromatin } \\
\text { nucleolus } \\
\text { 3) Early perinucleolus } \\
\text { 4) Late perinucleolus }\end{array}$ & $\begin{array}{l}\text { Oogonias and three substages of previtellogenic } \\
\text { oocyte observed simultaneously: chromatin nucleolus } \\
(\mathrm{Cn}) \text {, early perinucleolus (Pn1) and late perinucleolus. } \\
\text { In this species, a single large nucleolus located } \\
\text { eccentrically at the periphery of the nucleoplasm was } \\
\text { observed. Follicular cells surrounded all late } \\
\text { perinucleolus oocytes, and from this sub-stage, each } \\
\text { oocyte was nourished by its follicle. }\end{array}$ \\
\hline $\begin{array}{l}\text { Light orange color or light } \\
\text { brown with greenish tones }\end{array}$ & II Vitellogenesis & $\begin{array}{l}\text { Primary: } \\
\text { 5) Oil globule, } \\
\text { 6) Yolk globule } \\
\text { 7) Early vitellin } \\
\text { globule }\end{array}$ & $\begin{array}{l}\text { Primary vitellogenesis: } \\
\text { An overlap between previtelogenic and vitellogenic } \\
\text { oocytes was present, which caused to observe up to } \\
\text { five types of oocytes, but early vitellin oocyte (Ov1) } \\
\text { was the most frequent type. Ov1 had an ovoid shape } \\
\text { and began to form small lipid inclusions and small } \\
\text { slightly acidophilic granules with relatively uniform } \\
\text { size and accumulated in the periphery of the ovoplasm } \\
\text { below the vitelline membrane. Simultaneously, larger } \\
\text { oocytes with greater numbers of yolk granules at the } \\
\text { periphery of the ovoplasm were observed. Follicular } \\
\text { cells became flatter. } \\
\text { Secondary vitellogenesis: } \\
\text { Late vitelline globule oocytes were more repre- } \\
\text { sentatives and had diferent sizes. Arrangement of the } \\
\text { nucleolus and follicular cells resembled the previous } \\
\text { substage (Ov1). The oogonias and previtelogenic } \\
\text { oocytes were still present. }\end{array}$ \\
\hline Intense dark or purple color & III Maturity & $\begin{array}{l}\text { 9) Postvitellogenic } \\
\text { 10) Germinal vesicle } \\
\text { migration }\end{array}$ & $\begin{array}{l}\text { Postvitellogenic oocytes (Pvo) reached maximum } \\
\text { ovoplasm growth. Yolk granules were acidophilic in } \\
\text { nature and rich in triglycerides; they also reached } \\
\text { maximum size and oocytes were filled with them. } \\
\text { Follicular cells were flatter, and only one prominent } \\
\text { and round nucleolus was observed. }\end{array}$ \\
\hline Dark or lavender color & $\begin{array}{l}\text { IV Spawning / } \\
\text { Reabsorption }\end{array}$ & $\begin{array}{l}\text { 11) Germinal vesicle } \\
\text { breakdown }\end{array}$ & $\begin{array}{l}\text { Oocytes reached the maximum size of the theoretical } \\
\text { diameter, and no follicular cells were surrounding } \\
\text { them. The nucleus began to lose its circular shape, } \\
\text { migrating towards the periphery of the cytoplasm } \\
\text { where the germinal vesicle breaks down. Atretic } \\
\text { oocytes were observed. }\end{array}$ \\
\hline
\end{tabular}

nal vesicle migration oocytes, and a few (5\%) previtellogenic oocytes (chromatin nucleolus, early chromatin perinucleolus, and late chromatin perinucleolus).

In spawning and/or reabsorption stages, oocytes reached a maximum size of theoretical diameter (660 $\mu \mathrm{m})$, and no follicular cells were observed surrounding them. The nucleus began to lose its rounded shape, migrating towards the periphery of the cytoplasm where the germinal vesicle was in the breakdown (Figs. $1 \mathrm{~m}-1 \mathrm{n}$ ); atretic oocytes were also observed (Figs. 1o$1 \mathrm{p})$.
The immature ovary was not described microscopically because females in this stage were not obtained.

\section{Histochemical and quantitative analysis of oogenesis}

Significant differences $(P<0.05)$ were observed in theoretical mean diameter $(T D)$ between the oocytes of the different oogenesis stages (Table 3). The oocyte was initially small (49 to $129 \mu \mathrm{m})$ during the previtellogenic stage and increased gradually until primary $(185$ to $232 \mu \mathrm{m})$ and secondary vitellogenic stage $(321 \mu \mathrm{m})$, reaching a maximum of $580 \mu \mathrm{m}$ at the maturation stage (Table 3 ). 


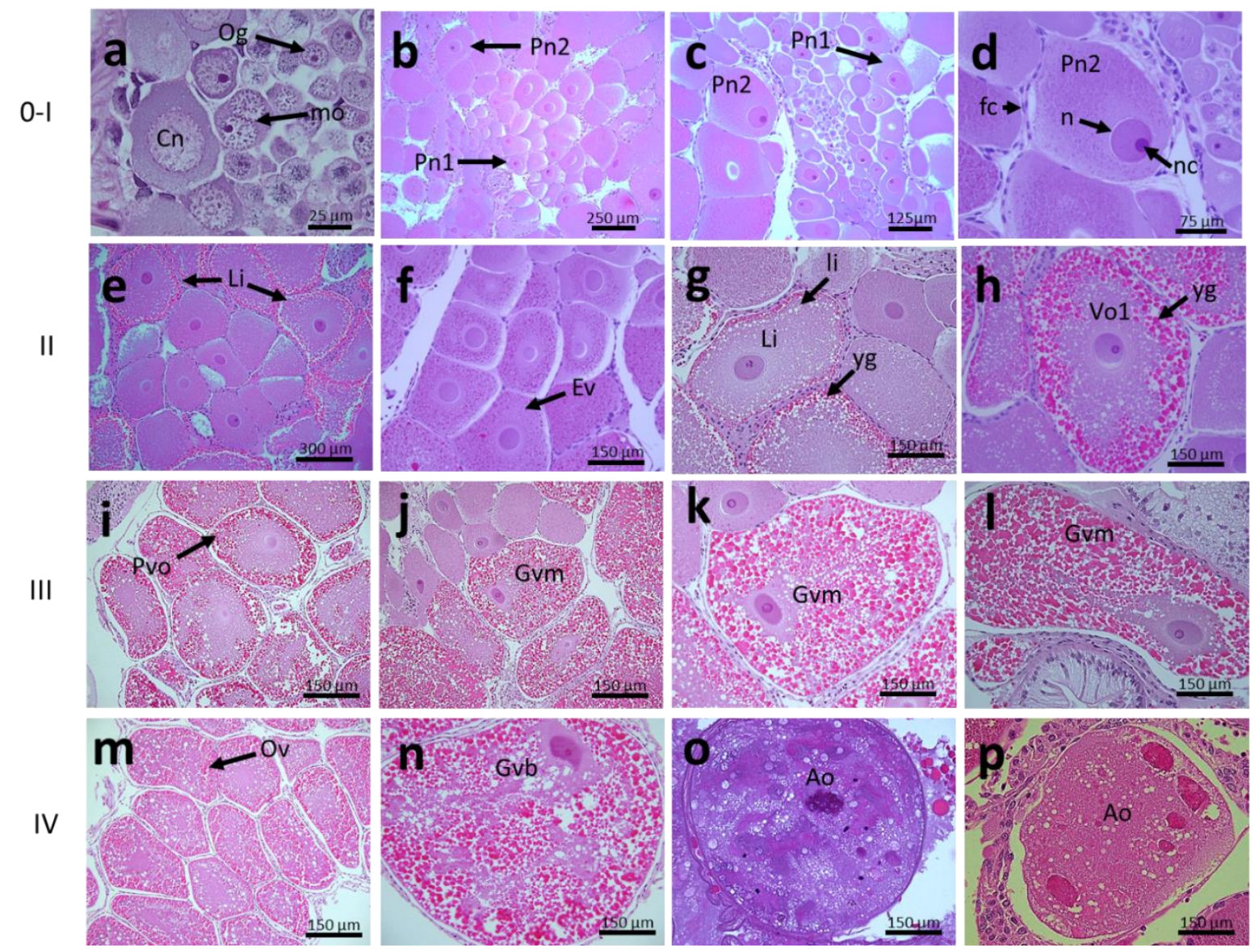

Figure 1. Photomicrographs of Lithodes santolla oogenesis. a) Ovary in stage 0 (multiplication) with multiplying oogonia $(\mathrm{Og})$, oogonium meiosis $(\mathrm{m})$ and oocytes in chromatin nucleolus $(\mathrm{Cn}) . \mathrm{a}), \mathrm{c}), \mathrm{d})$ ovary in stage I (previtellogenesis) with early perinucleolus oocytes (Pn1) and late perinucleolus oocytes (Pn2). e), f), g), h) ovary in stage II (vitellogenesis) with oil globule oocytes ( $\mathrm{Li})$ and yolk globules $(\mathrm{Yg})$; early vitelline globule oocytes (Ev1) and late vitelline globule oocytes (Vo1). i), j), k), l) ovary in stage III (maturity) with postvitellogenic oocytes (Pvo) and germinal vesicle migration (Gvm). $\mathrm{m}), \mathrm{n}), \mathrm{o}$ ), p) ovary in stage IV (spawning) with oocytes in germinal vesicle breakdown (Gvb) and atreic oocyte (Ao); li: oil globule; n: nucleus; nc: nucleolus; yg: yolk granulate; Ov: ovule; follicle cell. Hematoxylin and eosin stain.

The ANOVA analysis indicated significant differences $(P<0.05)$ in lipid content between the oogenesis stages (Table 3). Lipid content was initially low (Figs. 2a-2b) in oocytes of the previtellogenic stage (chromatin nucleolus, early perinucleolus and late perinucleolus oocytes); it increased gradually (Fig. 2c) in the oocytes of the primary (oil globule oocytes, yolk globules and early vitelline globule oocytes) and secondary vitellogenic stage (late vitellin globule oocytes) (Fig. 2d), reaching a maximum lipid content in postvitellogenic and germinal vesicle migration oocytes at the maturation stage (Table 3; Figs. 2e-2h).

\section{DISCUSSION}

Based on the histological and histochemical characteristics (size, cell morphology and distribution pattern, and H-E staining of yolk), five phases of the oogenesis cycle were identified, and furthermore, according to their cellular characteristics, 11 oocyte substages were distinguished in Lithodes santolla. Identification of oocyte development stages by histological, histochemical and yolk accumulation patterns in decapod crustaceans has been previously used in crabs (Varadarajan \& Subramoniam, 1980; Santos et al., 2009; Smija \& Sudha-Devi, 2015), shrimp (Yano, 1988; Tan-Fermin \& Pudadera, 1989; Kodama et al., 2009; El-Sheriff et al., 2012), and lobsters (Minagawa \& Sano, 1997; Feitosa-Silva \& Da Cruz-Landim, 2006).

In L. santolla, the particular organization of the oocytes, according to the morphological characteristics to the interior of the maturation lobes, suggests a synchronous oocyte maturation, which progresses as the 
Table 3. Mean \pm standard error of theoretical mean diameter (TD), lipid index and gonadosomatic index (GSI) for each oocyte substage identified in each stage of oogenesis of Lithodes santolla. *Gonadosomatic index was calculated as wet gonad weight $[(\mathrm{GW}) /$ wet weight of the entire female $(\mathrm{TW})] \times 100$. Superscript letters indicate significant differences after a one-way ANOVA $(P<0.05)$ and Tukey test.

\begin{tabular}{llcrc}
\hline Stages of oogenesis & Oocyte substages & GSI index ${ }^{*}$ & $\begin{array}{c}\text { Theoretical mean } \\
\text { diameter }(\mu \mathrm{m})^{*}\end{array}$ & $\begin{array}{c}\text { Lipid index } \\
(\%)^{*}\end{array}$ \\
\hline 0 Multiplication & -Oogonia & $1.95 \pm 0.18^{\mathrm{a}}$ & $23.45 \pm 1.42^{\mathrm{a}}$ & $10.79 \pm 0.61$ \\
\hline I Previtellogenesis & $\begin{array}{l}\text {-Chromatin nucleolus } \\
\text {-Early perinucleolus }\end{array}$ & $2.29 \pm 0.25^{\mathrm{a}}$ & $51.56 \pm 1.52^{\mathrm{b}}$ & $22.84 \pm 1.85^{\mathrm{b}}$ \\
& -Late perinucleolus & & $79.25 \pm 1.17^{\mathrm{c}}$ & $46.97 \pm 0.91^{\mathrm{c}}$ \\
& & & $126.34 \pm 2.38^{\mathrm{d}}$ & $58.99 \pm 1.30^{\mathrm{d}}$ \\
\hline II Vitellogenesis & -Oil globule, yolk globule & & $183.32 \pm 1.98^{\mathrm{e}}$ & $80.58 \pm 1.88^{\mathrm{e}}$ \\
& -Early vitellin globule & & & \\
& -Late vitellin globule & $4.96 \pm 0.47^{\mathrm{b}}$ & $229.74 \pm 2.64^{\mathrm{f}}$ & $82.58 \pm 0.82^{\mathrm{e}}$ \\
& & & & \\
& & & $418.22 \pm 3.79^{\mathrm{g}}$ & $84.84 \pm 0.53^{\mathrm{e}}$ \\
\hline III Maturity & -Postvitelogenic & & $462.83 \pm 6.58^{\mathrm{h}}$ & $96.25 \pm 2.19^{\mathrm{f}}$ \\
& -Germinal vesicle migration & $6.26 \pm 0.84^{\mathrm{c}}$ & $569.17 \pm 7.15^{\mathrm{i}}$ & $95.59 \pm 3.51^{\mathrm{f}}$ \\
\hline IV Spawning & -Germinal vesicle breakdown & $2.09 \pm 0.40^{\mathrm{a}}$ & $610.32 \pm 49.77^{\mathrm{i}}$ & $89.59 \pm 2.51^{\mathrm{ef}}$ \\
\hline
\end{tabular}

oocytes move away from the center of the ovary. This oocyte synchrony occurs in other decapod crustaceans (Yano, 1988; Tan-Fermin \& Pudadera, 1989; CeballosVázquez et al., 2003), finding the dominance of previtellogenic or vitellogenic oocytes according to the development state. The presence of oogonia, previtelogenic and vitellogenic oocytes, together with mature oocytes in stage IV of $L$. santolla oogenesis, suggests that some oocytes proliferate while others remain inactive, which shows the ability of females to perform more than one spawning event. Cytological and histological studies have shown that the oogenesis of females lasts 20-30 months but begins annually, and two parallel gametogenic cycles in the ovaries occur (Vinuesa, 1984; Vinuesa \& Labal de Vinuesa, 1998; Lovrich \& Vinuesa, 2016).

In this study, the histological analysis of the ovaries of females close to spawning suggested that ovulation and spawning occurred almost simultaneously, since no mature oocytes were found outside their follicles. In some species of decapod crustacean crabs, females carrying embryos close to hatching have ovaries in the advanced stage of maturity. This characteristic indicates that gonadal development in these species is usually concomitant with that of the embryo, indicating the ability of females to perform more than one spawning during their reproductive seasons (Oh et al., 2002; Meeratana \& Sobhon, 2007).

Similar to most decapod crustaceans, lithodid eggclutch production consists of phases of ovarian maturation, including primary oocyte formation and secondary vitellogenesis (lipogenesis) followed by ovoposition, fertilization, attachment to the pleopods and brooding of the eggs in the abdominal pouch. Oogenesis varies within and among lithodid species (Webb, 2014). For L. santolla reproducing for the first time, oogenesis duration is approximately two years with primary oocyte formation in the first year and secondary vitellogenesis in the following year (Vinuesa \& Labal de Vinuesa, 1998; Webb, 2014). Following the pubertal molt, these processes occur concurrently within the ovary, and mature oocytes are produced on an annual basis (Vinuesa \& Labal de Vinuesa, 1998). Longer duration of oogenesis is consistently two years for other lithodid species, such as Paralithodes platypus and $P$. camtschaticus, and three years for Paralomis granulosa (Lovrich \& Vinuesa, 1999). The ability to maintain concurrent formation of primary oocytes and secondary vitellogenesis varies with life history stage, so females reproduce annually for the first two reproductive cycles and biennially after that (Jensen \& Armstrong, 1989).

This study described the oogenesis process from the proliferation of oogonies to the final oocyte growth. The development of $L$. santolla oocytes can be correlated with a scale of visual maturity, based on the coloration of the ovaries (Table 2); however, histology allows us to define and measure ovarian developmental status and oocyte population more accurately. The visual scale, based on ovary coloration, can generate overlap between the states because $75 \%$ of previtellogenic oocytes and $25 \%$ of oocytes can be present in the state of previtellogenesis, initiating primary vitellogenesis; they are initially distributed to the peri- 

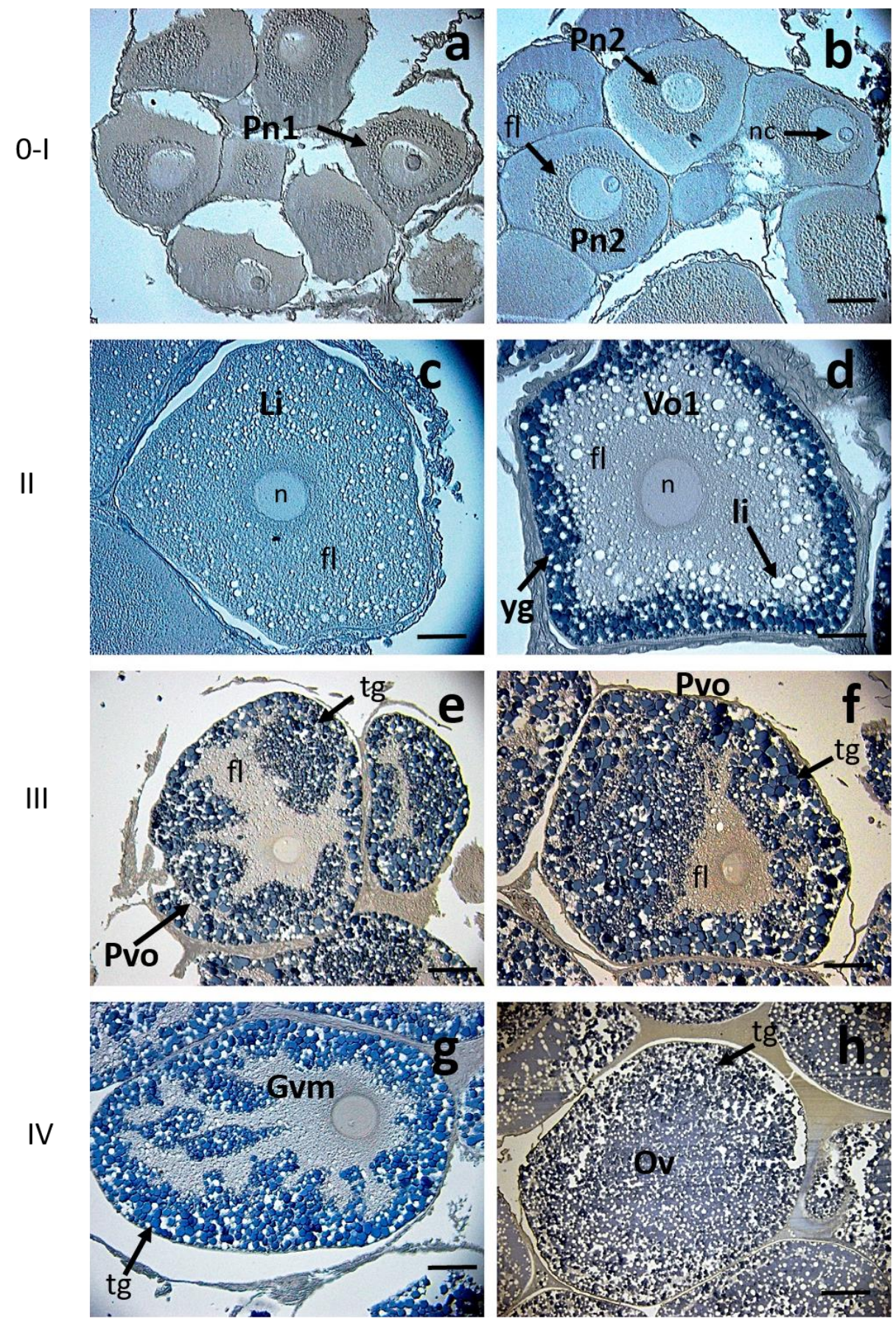

Figure 2. Micrographs of the histochemical lipid contents of oocytes during oogenesis of Lithodes santolla. a-b) Ovary in stage I (previtellogenesis) with early (Pn1) and late (Pn2) perinucleolus oocytes; scale bar $=50 \mu \mathrm{m}$; c-d) ovary in stage II (vitellogenesis) with oil globule (Li) and early vitellin globule (Vo1) oocytes; e-f) ovary in stage III (maturity) with postvitellogenic oocytes (Pvo); g-h) ovary in stage IV (spawning) oocyte with germinal vesicle migration (Gvm) and ovule (Ov). n: nucleus; nc: nucleolus; yg: yolk granulate; li: lipid globule; fl: phospholipids; tg: triglycerides; scale bar $=100 \mu \mathrm{m}$. Sudan Black stain.

phery of the ovarian lobes and gradually fill the lobe lumen, accompanied by oocytes in previtellogenesis, mainly oocytes in the early perinucleolus substage.
The reproductive system in $L$. santolla females follow the anatomical pattern observed in other lithodid species, such as $P$. camtschaticus and $P$. platypus (Webb, 2014): paired ovaries dorso-lateral to the 
digestive system, and connected in the middle, showing an " $H$ " shape, and oviducts, which are connected to gonopores located on the ventral surface of the exopodites of the second pereiopods. As in other species of decapod crustaceans, we found that coloration changes in the ovary are closely related to changes in the size of the oocytes inside the ovary. The size change in oocytes is mainly due to the rapid incorporation of yolk and lipid drops (Quackenbush, 1989; Yano et al., 1996), which appear at the beginning towards the periphery of the cytoplasm, indicating the final stage of the state of previtellogenesis and the beginning of primary vitellogenesis.

The importance in describing the average size of oocytes during oogenesis is that females of decapod crustaceans from the same population may show the same pattern of ovarian maturation in terms of coloration, distribution of the oocytes within the ovary, and synchrony of previtellogenic, vitellogenic and mature oocytes, but not the same size, showing smaller oocytes for all development stages and consequently smaller and lower quality larvae (Palacios et al., 1999; Ceballos-Vázquez et al., 2003; Arcos et al., 2005, 2011). In L. santolla, this knowledge is of vital importance. In this sense, reproduction is a critical event in the life history of animals; one of the indices for determining the reproductive status of marine invertebrates is based on the observation of gonadal maturation (Giese \& Pearse, 1974; RodríguezJaramillo et al., 2008; Ravi et al., 2012; Smija \& SudhaDevi, 2015), both at the macroscopic (color, weight and shape of gonads) and microscopic levels (histological and histochemical oocyte characteristics). The description of $L$. santolla reproductive cycle is needed to achieve its maturation in captivity and for fishery resource management. Considering that conservation and management decisions must be made using the best available scientific information, oogenesis knowledge and estimates of different indicators, such as the GSI, will allow estimating the "reproductive effort," age of first sexual maturity, time and place of reproduction and factors that affect the reproductive process of $L$. santolla. This information will allow providing a regulation for resource capture and permits to establish adequate closure periods that guarantee that fishing effort is proportional to the productive "reproductive" capacity. "Reproductive effort" has been defined as the proportion of body energy shifted to reproduction and gonadosomatic index, estimated as gonadal weight/ total body weight, which is one of the most common and simple quantitative methods currently used to evaluate "reproductive effort" (Tsuchida \& Watanabe, 1997; López-Greco \& Rodríguez, 1999) because it accumulates energy reserves. For $L$. santolla, it is particularly important because no scientific evidence is still available to predict population productivity with confidence. Furthermore, the most incipient threat is the depletion of reproductive populations, so they should be maintained at productive levels to ensure reproduction sites and permanence of this species in the Magellan and Chilean Antarctic Region.

In L. santolla, histological H-E and histochemical analysis demonstrated changes in nuclear appearance and cytoplasmatic granulation of oocytes, and significant yolk accumulation during the vitellogenesis stages of oogenesis. The secondary vitellogenic stage is marked by the uniform appearance of yolk globules and lipids in the cytoplasm, except for the clear perinuclear area. Yolk droplets, uniform in size in all cytoplasm, may be the result of a condensation process related to the accumulation of yolk substances distributed in the cytoplasm and an extra-ovarian origin of yolk proteins (Quackenbush, 1989; Yano et al., 1996). However, immunolocalization of yolk proteins and analysis of gene expression are needed to determine the origin of yolk droplets.

The histochemical analyses indicated a remarkable increase of lipids with the primary vitellogenesis stage. Ultrastructural and biochemical studies have shown a similar pattern in other species of crustacean decapods, such as the crab Clibanarius clibanarius (Varadarajan \& Subramoniam, 1980) and brachyuran crabs, such as Travancoriana schirnerae (Smija \& Sudha-Devi, 2015). In the anomura crab C. clibanarius, lipids are present from early vitellogenesis, as in L. santolla, and suggest an exogenous supplement (Varadarajan \& Subramoniam, 1980). The increase of triglycerides and decrease of phospholipids during vitellogenesis and postvitelogénesis has been observed in Pacific white shrimp Litopenaeus vannamei (Corral-Rosales et al., 2018), by the same Sudan Black B stain, used in this study.

Incorporation of lipovitellins from labeled femalespecific proteins into vitellogenic oocytes is characteristic in decapod crustaceans (Adiyodi \& Subramoniam, 1983). The appearance of lipids in the periphery and their spread into the cytoplasm form a complex of yolk droplets in the vitellogenic oocytes. Smaller yolk spheres observed at the start of the maturity stage could indicate incorporation of lipovitellins during $L$. santolla oogenesis.

In this study, red color in $L$. santolla ovaries occurred at the maturity stage. The same color has been observed in crab species: Portunus sanguinolentus (Ryan, 1967), Libinia emarginata (Hinsch, 1972), Carcinus maenas (Laulier \& Demeusy, 1974), Callinectes sapidus (Johnson, 1980) and Uca rapax 
(Castiglioni et al., 2007). Red may come from an external supply of carotenoid from an extra-oocytic source. In $L$. santolla, the lipoproteins from extraovarian sources may be linked to carotenoid pigments, serving as carriers facilitating entry of lipoproteins into oocytes, as it was suggested for the anomura crab C. clibanaurius (Varadarajan \& Subramoniam, 1980).

The results of this study showed that oocyte diameter, measured by histology, reflected yolk accumulation in the oocytes, allowing for the definition of differences between the oogenesis stages. Furthermore, this quantitative histological variable provided an accurate indicator of female reproductive activity and oogenesis status. In this context, oocyte diameter measured by histology has been reported as an indicator of ovary condition of crustacean decapods (Yano, 1988; Tan-Fermin \& Pudadera, 1989; Arcos et al., 2005; Smija \& Sudha-Devi, 2015).

Oogenesis of lithodid species, such as L. santolla, has been studied by several authors (Webb, 2014; Lovrich \& Vinuesa, 2016); methods used to evaluate maturity in female and male lithodids include gonad maturation, morphometric relationships and mating ability (Webb, 2014). Functional maturity of female lithodids is typically determined by a single method, the size at which females are observed to be brooding egg clutches (ovigerous), and size at maturity is estimated by logistic regression of carapace length when $50 \%$ of females are ovigerous (Vinuesa, 1985; Webb, 2014). To our knowledge this study is the first characterization of the phases, based on changes in ovary size and coloration, contrasting with modifications in the internal gonad morphology and the first quantitative description based on yolk size and accumulation during the different oogenesis stages. The exploitation of $L$. santolla in the Magellan and Chilean Antarctic Region takes place in an extensive area (SUBPESCA, 2014), in which differences in terms of resource and effort distribution, capture mode and organizational level of the fishing communities have been observed. Therefore, for the fishery management plan, obtaining reproductive physiological knowledge that allows adequate protection of the reproductive process of the target population could be the key to making $L$. santolla fishery sustainable.

\section{ACKNOWLEDGMENTS}

This research was supported by CORFO (12BPC213541) and FIC R-2012 (30127734-0) grants from CEQUA to E. Paola Acuña Gómez and G. Fabiola Arcos. The authors thank CEQUA staff: María Teresa Ramírez, Freddy Muñoz, Mario Esquivel, Cecilia
Ramírez, Carlos Olave, Manuel Sánchez, Guillermo Alvarado, Oscar Mancilla, Carla Mora, Johana Ruiz, Marcos Pinto, Gabriel Quilahuilque, Edy Cadín, Jéssica Azócar, Rocío Canche, and Juan Ríos. We are indebted to CIBNOR for their infrastructure and technical support and grateful to Eulalia Meza Chávez for histological and histochemical technical support; to Diana Fischer for editorial services in English.

\section{REFERENCES}

Adiyodi, R.G. \& Subramonia, T. 1983. Oogenesis, oviposition, and absorption. In: Adiyodi, K.G. \& Adiyodi, R.G. (Eds.). Reproductive biology of invertebrates. Wiley, New York, pp. 443-495.

Alfaro-Montoya, J. 2013. Descripción histológica de la oogenesis y espermatogénesis del camarón de cultivo, Litopenaeus vannamei. Revista de Biología Marina y Oceanografía, 48(2): 335-344.

Arcos, F.G., Racotta, I.S., Palacios, E. \& Ibarra, A.M. 2005. Ovary development at the onset of gametogenesis is genetically determined and correlated with reproductive traits at maturity in shrimp Litopenaeus (Penaeus) vannamei. Marine Biology, 148: 339-346.

Arcos-Ortega, F.G., Ibarra, A.M. \& Racotta, I.S. 2011. Vitellogenin in hemolymph predicts gonad maturity in adult female Litopenaeus (Penaeus) vannamei shrimp. Aquaculture, 316: 93-98.

Bayliss, H.O. 1984. Lipid histochemistry. Department of Pathology, Guy's Hospital Medical School. Oxford University Press, London.

Bembe, S.E. 2009. Reproductive physiology of the female blue crab Callinectes sapidus: spawning induction and vitellogenesis. M.Sc. Thesis, University of Maryland, College Park, Maryland.

Castiglioni, D.S., Negreiros-Fransozo, M.L., LópezGreco, I.S., Silveira, A.F. \& Silveira, S.O. 2007. Gonad development in females of fiddler crab Uca rapax (Crustacea, Brachyura, Ocypodidae) using macro and microscopic techniques. Iheringia, Série Zoologia, 97(4): 505-510.

Ceballos-Vázquez, B.P., Rosas, C. \& Racotta, I.S. 2003. Sperm quality in relation to age and weight of white shrimp Litopenaeus vannamei. Aquaculture, 228: 141151.

Corral-Rosales, D.C., Cruz-Suárez, L.E., Ricque-Marie, D., Rodríguez-Jaramillo, C. \& Palacios, E. 2018. Modulation of reproductive exhaustion using Ulva clathrata in Pacific white shrimp Litopenaeus vannamei (Boone, 1931) broodstock during commercial maturation. Aquaculture Research, 49 (12): 3711-3722. 
El-Sherif-Sohier, S., Gihan, M., El-Khodary, B., Amal, Z. \& Ghonim, Z. 2012. Ovarian cycle and scanning electron micrographs of the spawned egg of female mantis shrimp Oratosquilla massavensis (Alexandria, Egypt). The Journal of Basic and Applied Zoology, 65: 116-124.

Feitosa-Silva, J.R. \& Da Cruz-Landim, C. 2006. Macroscopic aspects and scanning electron microscopy of the ovaries of the spiny lobsters Panulirus (Crustacea: Decapoda). Brazilian Journal of Morphological Sciences, 23(3-4): 479-486.

Hinsch, G.W. 1972. Some factors controlling reproduction in the spider crab, Libinia emarginata. Biological Bulletin, 143: 358-366.

Humanson, G.L. 1979. Animal tissue techniques. W.H. Freeman, San Francisco.

Jensen, G.C. \& Armstrong, D.A. 1989. Biennial reproductive cycle of blue king crab, Paralithodes platypus, at the Pribilof Islands, Alaska, and comparison to a congener $P$. camtschatica. Canadian Journal of Fisheries and Aquatic Sciences, 46: 932-940.

Johnson, P.T. 1980. Histology of the blue crab Callinectes sapidus: a model for Decapoda. Praeger Publishers, New York.

Kodama, K., Shiraishi, H., Morita, M. \& Horiguchi, T. 2009. Reproductive biology of the Japanese mantis shrimp Oratosquilla oratoria (Crustacea Stomatopoda): annual cycle of gonadal development and copulation. Marine Biology Research, 5(5): 415-426.

Laulier, M. \& Demeusy, N. 1974. Étude histologique du fonctionnement ovarien au cours d'une maturation de ponte chez le crabe Carcinus maenas L. (Crustacé, Décapode). Cahiers de Biologie Marine, 15(3): 343354.

López-Greco, L.S. \& Rodríguez, E.M. 1999. Annual reproduction and growth of adult crabs Chasmagnathus granulate (Crustacea, Brachyura, Grapsidae). Cahiers de Biologie Marine, 40: 155-164.

Lovrich, G.A. \& Vinuesa, J.H. 1999. Reproductive potential of the lithodids Lithodes santolla and Paralomis granulosa in the Beagle Channel, Argentina. Scientia Marina, 63: 355-360.

Lovrich, G.A. \& Vinuesa, J.H. 2016. Biología de las centollas (Anomura: Lithodidae). El Mar Argentino y sus Recursos Pesqueros, 6: 183-212.

Minagawa, M., Chiu, J.R., Kudo, M., Ito, F. \& Takashima, F. 1993. Female reproduction biology and oocyte development of the red frog crab, Ranina ranina, of Hachijojima, Izu Islands, Japan. Marine Biology, 115: 613-623.

Minagawa, M. \& Sano, M. 1997. Oogenesis and ovarian development cycle of the spiny lobster Panulirus japonicus (Decapoda: Palinuridae). Marine and Freshwater Research, 48: 875-887.
Oh, C.W., Suh, H.L., Park, K.Y., Ma, C.W. \& Lim, H.S. 2002. Growth and reproductive biology of the freshwater shrimp Exopalaemon modestus (Decapoda: Palaemonidae) in a lake of Korea. Journal of Crustacean Biology, 22(2): 357-366.

Otsu, N. 1979. A threshold selection method from greyleve1 histograms. IEEE Transactions on Systems, Man, and Cybernetics: Systems, 9: 62-66.

Palacios, E., Rodríguez-Jaramillo, C. \& Racota, I.S. 1999. Comparison of ovary histology between differentsized wild and pond-reared shrimp Litopenaeus vannamei (=Penaeus vannamei). Invertebrate Reproduction \& Development, 35(3): 251-259.

Peixoto, S., Cavalli, R.O., D'Incao, F., Milach, Â.M. \& Wasielesky, W. 2003. Ovarian maturation of wild Farfantepenaeus paulensis in relation to histological and visual changes. Aquaculture Research, 34: 12551260 .

Quackenbush, L.S. 1989. Vitellogenesis in the shrimp, Penaeus vannamei: in vitro studies of the isolated hepatopancreas and ovary. Comparative Biochemistry and Physiology, 94: 253-261.

Ravi, R., Manisseri, M.K. \& Sanil, N.K. 2012. Ovarian maturation and oogenesis in the blue swimmer crab, Portunus pelagicus (Decapoda: Portunidae). Acta Zoologica, 20: 1-9.

Rodríguez-Jaramillo, C., Hurtado, M.A., Romero-Vivas, E., Ramírez, J.L., Manzano, E. \& Palacios, E. 2008. Gonad development and histochemistry of the tropical oyster Crassostrea corteziensis (Hertlein, 1951) during an annual reproductive cycle. Journal of Shellfish Research, 27: 1129-1141.

Ryan, E.P. 1967. Structure and function of the reproductive system of the crab Portunus sanguinolentus (Herbst) (Brachyura: Portunidae). II. The female system. Proceedings of the Symposium on Crustacea. Journal of the Marine Biological Association of India, 2: 522-544.

Sainte-Marie, B., Raymond, S. \& Brethes, J.C. 1995. Growth and maturation of the benthic stages of male snow crab, Chionoecetes opillo (Brachyura: Majidae). Canadian Journal of Fisheries and Aquatic Sciences, 52: 903-924.

Sampedro, M.P., González-Gurriarán, E., Freire, J. \& Muiño, R. 1999. Morphometry and sexual maturity in the spider crab Maja squinado (Decapoda: Majidae) in Galicia, Spain. Journal of Crustacean Biology, 19: 578-592.

Santos, C.M., Lima, G.V., Nascimento, A.A., Sales, A. \& Oshiro, L.M.Y. 2009. Histological and histochemical analysis of the gonadal development of males and females of Armases rubripes (Rathbun, 1897) (Crustacea, Brachyura, Sesarmidae). Brazilian Journal of Biology, 69(1): 161-169. 
Saout, C., Paulet, Y.M. \& Duinker, A. 1999. Histological study on the early stages of oogenesis in Pecten maximus: a new approach with quantitative semi-thin histology. 12th International Pectinid Workshop, Bergen, pp. 129-130.

Smija, M.K. \& Sudha-Devi, A.R. 2015. Oocyte development and female reproductive cycle in the freshwater crab Travancoriana schirnerae. Turkish Journal of Fisheries and Aquatic Sciences, 15: 691702.

Subsecretaría de Pesca (SUBPESCA). 2014. Modificación veda biológica centolla (Lithodes santolla), Región de Magallanes y Antártica chilena. Subsecretaría de Pesca y Acuicultura, Ministerio de Economía, Chile, Informe Técnico (Rec. Pesq.), 208/2014: 19 pp. [http://www.subpesca.cl/portal/618/articles-87132 documento.pdf ]. Reviewed: 15 April 2018.

Tan-Fermin, J.D. \& Pudadera, R.A. 1989. Ovarian maturation stages of the wild giant tiger prawn Penaeus monodon (Fabricius). Aquaculture, 77: 229242.

Tsuchida, S. \& Watanabe, S. 1997. Growth and reproduction of the grapsid crab Plagusia dentipes (Decapoda: Brachyura). Journal of Crustacean Biology, 17(1): 90-97.

Varadarajan, S. \& Subramoniam, T. 1980. Histochemical investigations on vitellogenesis of an anomuran crab, Clibanarius clibanarius. International Journal of Invertebrate Reproduction, 2(1): 47-58.

Received: 11 July 2018; Accepted: 11 March 2019
Vinuesa, J.H. 1984. Sistema reproductor, ciclo y madurez gonadal de la centolla (Lithodes antarcticus) del Canal Beagle. Instituto Nacional de Investigación y Desarrollo Pesquero, 441: 75-95.

Vinuesa, J.H. 1985. Differential aspects of the southern king crab (Lithodes antarcticus) in two latitudinally separated locations. In: Melteff, B. (Ed.). Proceedings of the International King Crab Symposium, Alaska Sea Grant, 85(12): 267-279.

Vinuesa, J.H. \& Labal de Vinuesa, M.L. 1998. La gametogénesis de la centolla, Lithodes santolla (Molina, 1782) (Crustacea, Decapoda, Lithodidae). Naturalia Patagonica, Ciencias Biológicas, 6: 35-49.

Webb, J. 2014. Reproductive ecology of commercially important lithodid crabs. In: Stevens, B.G. (Ed.). King crabs of the world. Biology and fisheries management. CRC Press, Florida.

Yano, I. 1988. Oocyte development in the kuruma prawn Penaeus japonicus. Marine Biology, 99: 549-553.

Yano, I., Krol, R.M., Overstreet, R.M. \& Hawkins, W.E. 1996. Route of egg yolk protein uptake in the oocytes of kumura prawn, Penaeus japonicus. Marine Biology, 125: 773-781.

Zar, J. H. 1999. Biostatistical analysis. Prentice-Hall, New Jersey. 